\title{
HALAL PRODUCTION AT THE MEATBALL HOME INDUSTRY IN BENGKULU CITY \\ Miti Yarmunida ${ }^{1}$, Nilda Susilawati ${ }^{2}$ Khairiah El-Wardah ${ }^{3}$ \\ miti_yarmunida@iainbengkulu.ac.id ${ }^{1}$, nilda79@iainbengkulu.ac.id ${ }^{2}$, khairiahelwardah@,iainbengkulu.ac.id ${ }^{3}$
}

\begin{abstract}
,
Halal certification is a must in the culinary field, especially in supporting Indonesia as a world halal tourism destination. However, the phenomenon that is developing in the city of Bengkulu, there are still many processed foods, especially flour and meat such as meatballs, which are very popular with the public, do not have a halal certificate in their sales In fact, there is only 1 meatball business in Bengkulu that is registered in the 2020 LPPOM MUI halal product shopping. Thus, the purpose of this study is to describe how the process of production of food processed with flour and meat, which is mostly a category of home industry in Bengkulu City, and analyzes it using production theory in Islam. This research method is descriptive qualitative. Research informants were home industry food producers, namely food producers from processed meat and flour. This business does not yet have a brand or production permit from the related party, even though they produce the food every day and it is sold freely in the city of Bengkulu. The research instrument was an open interview guide to dig deeper into the information about the production process that the informant did. Data analysis through restatement, description and interpretation of data. The results of the study found that the meatball home industry food production process in Bengkulu City has not had a halal standard of production as regulated in production theory in Islam. This happened on the background of the lack of knowledge of home industry players about halal production and tended not to consider the issue of halal label and production permits from related parties as important.
\end{abstract}

Keywords: Halal production, home industry

Received: December 22 ${ }^{\text {nd }}, 2020$; Revised: Mei 05 ${ }^{\text {th }}, 2021$; Accepted: June 25 ${ }^{\text {nd }}, 2021$

1,2,3Institut Agama Islam Negeri Bengkulu and Jl. Raden Fatah Pagar Dewa Kota Bengkulu

E-mail: ${ }^{1}$ miti yarmunida@,iainbengkulu.ac.id, ${ }^{2}$ nilda79@,iainbengkulu.ac.id, 3 khairiahelwardah@,iain

bengkulu.ac.id

DOI: https://doi.org/10.24952/tijaroh.v6i2.2453 


\section{Introduction}

The people of Bengkulu City are predominantly Muslim, of course, they need halal consumption. The value of the philosophy of halal in Islamic economics is that humans who consistently take care of whatever they consume are guaranteed halal and its benefits, then Allah swt guarantees that their lives will be safe in the world and the hereafter (Ridwan, 2019). One of the foods that are loved by many people is meatball. The number of meatball traders in Bengkulu City continues to increase, while those who are LPPOM halal certified by the end of 2020 are only 1 meatball producer, namely the Super Cah Solo Meatball producer on Jalan Tanah Patah, Bengkulu City (LPPOM MUI, 2019). Even though the guarantee of the halalness of this product has been regulated and every product circulating on the market must be certified halal, but the phenomenon in the field is that there are still producers who use a mixture of pork, borax (a dangerous substance) in meatball balls. (Zilhadia, Adhiyanto, Gustida, \& Khairunnisa, 2020) (Almunawaroh \& Ulviah, 2020). Consumers cannot tell which meatballs are not mixed with pork and / or borax because this type of food is the result of mixing several ingredients into one unit. Thus, it is difficult to tell the difference if it has been processed into meatballs unless checked with a detection tool. According to law number 33 of 2014 concerning the guarantee of halal products, small businesses are required to be halal certified, if by 2024 they are not certified halal then they will receive sanctions.

Halal Product Process is a series of activities to ensure the halalness of a Product, including the provision of materials, processing, storage, packaging, distribution, sales and presentation of Products. This series of production processes must ensure its halalness because Allah Almighty commands humans to consume what is on this earth that is halal and good. As contained in Qs. Al-Baqarah verse 168 which means: $\mathrm{O}$ all human beings, eat what is clean and good from what is on earth, and do not follow the steps of Satan; because actually Satan is a real enemy to you.

Production in Islam does not only consider benefits and benefits, but there is an aspect that is much more mainstream, namely the ta'abbdu ilallahi ta'ala aspect. So that all aspects of production will have a positive effect (mashlahah) for both producers, consumers and the surrounding environment (Rafsanjani, 2016). Every producer who will take care of a halal certificate for their products must meet the criteria set by LPPOM MUI as the institution with the authority to issue halal certificates (Ma'rifat \& Sari, 2017). Recognition of halal guarantees is needed by producers as a guarantee for food safety, quality and other important 
Miti Yarmunida, Nilda Susilawati, Khairiah El-Wardah

Halal Production at The Meatball Home Industry In Bengkulu City

characteristics that are not only enjoyed by Muslim consumers but also non-Muslim consumers. Based on the description above, the writer will review and analyze the production implementation whether it is in accordance with the halal assurance system established by LLPOM MUI.

Production is a process of converting input into output by emphasizing efforts to obtain maximum profits, which are not only oriented towards goods and services (Karim, 2007). The results of the production process in the form of products will be thrown into the market to meet the needs of the community(Carthy, Jerome, 2003). Products are goods and / or services related to food, beverages, medicines, cosmetics, chemical products, biological products, genetically engineered products, and consumer goods that are used, used, or utilized by the community (Law No. 33 2014)

In Islam, production is understood as a process that emphasizes efforts to maximize efficiency and profit. Production is not only profit oriented but also aspects of worship and ethics (Karim, 2007). Worship in the aspect of hablum minannaas in the frame of religious norms that prioritizes halal and thoyyib. In Islamic economics there are several principles of production that refer to maqashid al-sharia, namely: (i) The production process must be based on Islamic values and maqashid al-sharia. Production activities do not conflict with efforts to preserve religion, mind, soul, descent and property. (2). Production priorities are oriented towards fulfilling needs, namely dharuriyat, hajiyat and tahsiniyat, by paying attention to aspects of social justice such as zakat, donations, alms and endowments. (iv) processing and maintaining natural resources optimally, not destroying the environment and wasteful. (v) distributing profits fairly to owners, managers, management and employees(Fauzia and Royadi, 2014).

Consuming halal and good food is a Muslim obligation. The amount of halal food is far more than that which is haram. However, products mixed with haram or najis are still circulating, causing consumer concern. The regulation made by the government by requiring producers to include a halal logo on products that are halal certified is one of the solutions and guidelines for consumers to ensure the halalness of the product.

The halal certificate issued by MUI is a form of statement of the halalness of a product that has been tested and researched by the MUI auditor, which guarantees the halalness of the product, thereby providing a sense of security for the public who will use or consume a product, such as food, cosmetics and medicines. MUI is an institution appointed by the government to manage the halal certification of products in Indonesia (Segati, 2018). 
Producers can apply for product certification through the procedure stages as stated in the Halal Assurance System (HAS). The Halal Assurance System is a mechanism that producers must implement when applying for halal certification, which includes 11 halal criteria before being tested at LPPOM MUI. Recognition of the halalness of products by MUI guarantees Muslim and non-Muslim consumers of the halalness of the product, in order to provide a sense of security and calm in consuming the product (Baharuddin, et al. 2015). Consciousness of halalness will have a positive influence on consumers' desire to buy and use (Hapsari et al., 2019). The halal certification procedure implemented by BPJPH are the following stages:

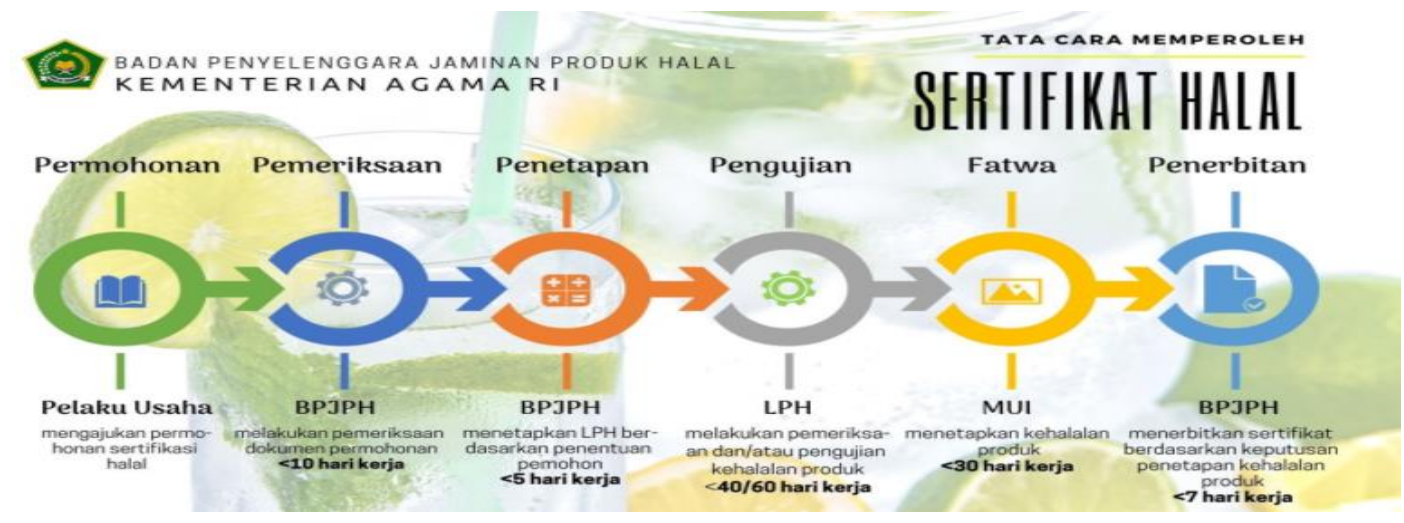

Figure 1. The Halal Certification Procedure

Source: BPJPH Kementerian Agama RI 2020

Halal product is a product that is produced from every chain of the production process that is free from things that are forbidden. The production process includes the supply, transportation, transformation process, packaging, and control (Gemasih, 2014).

Table 1. Prohibited Matters in the Production Process

\begin{tabular}{cll}
\hline No & Production Resources & \multicolumn{1}{c}{ Illegal Causes } \\
\hline $\mathbf{1}$ & Finance & $\begin{array}{l}\text { Sources of capital and financing in the production } \\
\text { process come from non-halal sources. }\end{array}$ \\
$\mathbf{2}$ & Raw material & $\begin{array}{l}\text { Sources of capital and financing in the production } \\
\text { process come from non-halal sources. }\end{array}$ \\
$\mathbf{3}$ & Tools and Machines & $\begin{array}{l}\text { Does not contain any type or raw material that is } \\
\text { banned as stated above. }\end{array}$ \\
4 & Mechanism & $\begin{array}{l}\text { Contamination of the product during the production } \\
\text { process by ingredients that are harmful or have a } \\
\text { negative impact on the consumers }\end{array}$ \\
& &
\end{tabular}

Source : (Gemasih, 2014)

The processing of halal products is carried out through research related to raw materials, processing, packaging, storage, distribution and marketing in accordance with MUI halal standards (Faridah, 2019). Through the halal assurance system, producers have directed and 
Miti Yarmunida, Nilda Susilawati, Khairiah El-Wardah

Halal Production at The Meatball Home Industry In Bengkulu City

measurable halal management and are strong empirical evidence that the halal supply chain can be achieved through the application of halal certification (Zainuddin et al., 2019), (Ahmad, Rahman and Rahman, 2015). The public can ensure that a product has been certified halal by looking at the list of halal certificates at LPPOM MUI. The public needs accurate information about the ingredients used in the production of processed animal products so they are not manipulated negatively by producers (Purnomo, et al. 2015), because the halalness of products can influence consumers to buy products (Sardiana, 2020), (Marzuki, Hall and Ballantine, 2014). The halal brand is also a separate market for producers to be developed (Mohtar, Amirnordin and Haron, 2014) and able to compete with other products.

Food consumed by Muslims is prohibited from containing haram ingredients, including raw materials, food additives, auxiliary materials and other supporting materials. Materials that are processed through genetic engineering and food irrigation and processing are carried out in accordance with Islamic law (Law Number 69, 1999). According to Astawan, meatball is a processed meat product mixed with flour and other ingredients (Pratiwi et al. 2020), safe for consumption by complying with Indonesian National Standards with $70 \%$ water content, $10 \%$ maximum fat content, $11 \%$ minimum protein content, ash content. maximum $3 \%$ and without preservatives in the product.

Tabel 2. SNI 3818- Quality Requirements for Meatballs

\begin{tabular}{|c|c|c|c|c|}
\hline \multirow[t]{2}{*}{ No } & \multirow[t]{2}{*}{ Test Criteria } & \multirow[t]{2}{*}{ Unit } & \multicolumn{2}{|c|}{ Requirements } \\
\hline & & & Meatballs & $\begin{array}{l}\text { Combination } \\
\text { Meatballs }\end{array}$ \\
\hline 1 & Condition & & & \\
\hline 1.1 & Smell & - & $\begin{array}{l}\text { Normal, typical } \\
\text { meat }\end{array}$ & $\begin{array}{l}\text { Normal, typical } \\
\text { meat }\end{array}$ \\
\hline 1.2 & Taste & - & $\begin{array}{l}\text { Normal typical } \\
\text { meatball }\end{array}$ & $\begin{array}{l}\text { Normal typical } \\
\text { meatball }\end{array}$ \\
\hline 1.3 & Colour & - & Normal & Normal \\
\hline 1.4 & Tekstur & - & Chewy & Chewy \\
\hline 2 & Water content & $\begin{array}{c}\%(\mathrm{~b} / \mathrm{b}) \\
\text { Maks }\end{array}$ & $\begin{array}{l}70,0 \\
\text { Maks }\end{array}$ & 70,0 \\
\hline 3 & Ash Rate & $\%(b / b)$ & Maks. 3,0 & Maks. 3,0 \\
\hline 4 & Kadar Protein (N x 6,25) & $\%(b / b)$ & Min. 11,0 & Min. 8,0 \\
\hline 3 & Fat Content & $\%(b / b)$ & Maks. 10,0 & Maks. 10,0 \\
\hline 6 & Cemaran Logam & & & \\
\hline 6.1 & Kadmium (Cd) & $\mathrm{mg} / \mathrm{kg}$ & Maks. 0,3 & Maks. 0,3 \\
\hline 6.2 & Timbal (Pb) & $\mathrm{mg} / \mathrm{kg}$ & Maks. 1,0 & Maks. 1,0 \\
\hline 6.3 & Timah (Sn) & $\mathrm{mg} / \mathrm{kg}$ & Maks. 40,0 & Maks. 40,0 \\
\hline 6.4 & Merkuri (Hg) & $\mathrm{mg} / \mathrm{kg}$ & Maks. 0,03 & Maks. 0,03 \\
\hline 7 & Cemaran Arsen (As) & $\mathrm{mg} / \mathrm{kg}$ & Maks. 0,5 & Maks. 0,5 \\
\hline
\end{tabular}


8 Cemaran Mikroba

8.1 Angka Lempeng Total

8.3 Escherichia coli

8.4 Salmonella sp.

8.5 Staphylococcus aureus

8.6 Clostridium perfringens

Source : (SNI 3818, 2014) koloni/g

$\mathrm{APM} / \mathrm{g}$

$\mathrm{APM} / \mathrm{g}$

Maks. $1 \times 10^{5}$

Maks. 10

$<3$

Negatif/25 g

koloni/g Maks. $1 \times 10^{2}$

koloni/g
Maks. 1 x $10^{3}$

Maks. 10

$<3$

Negatif/25 g

Maks. 1 x $10^{2}$

Maks. $1 \times 10^{2}$

Animal ingredients are a critical point in halal processing of products. The animals used are halal animals in the aspect of slaughter as regulated in the RPH LPPOM MUI that the slaughterhouse must comply with Islamic law. The processing of animal ingredients by mixing with other raw materials such as flour, eggs, oil, flavorings and other ingredients allows it to mix with haram substances.

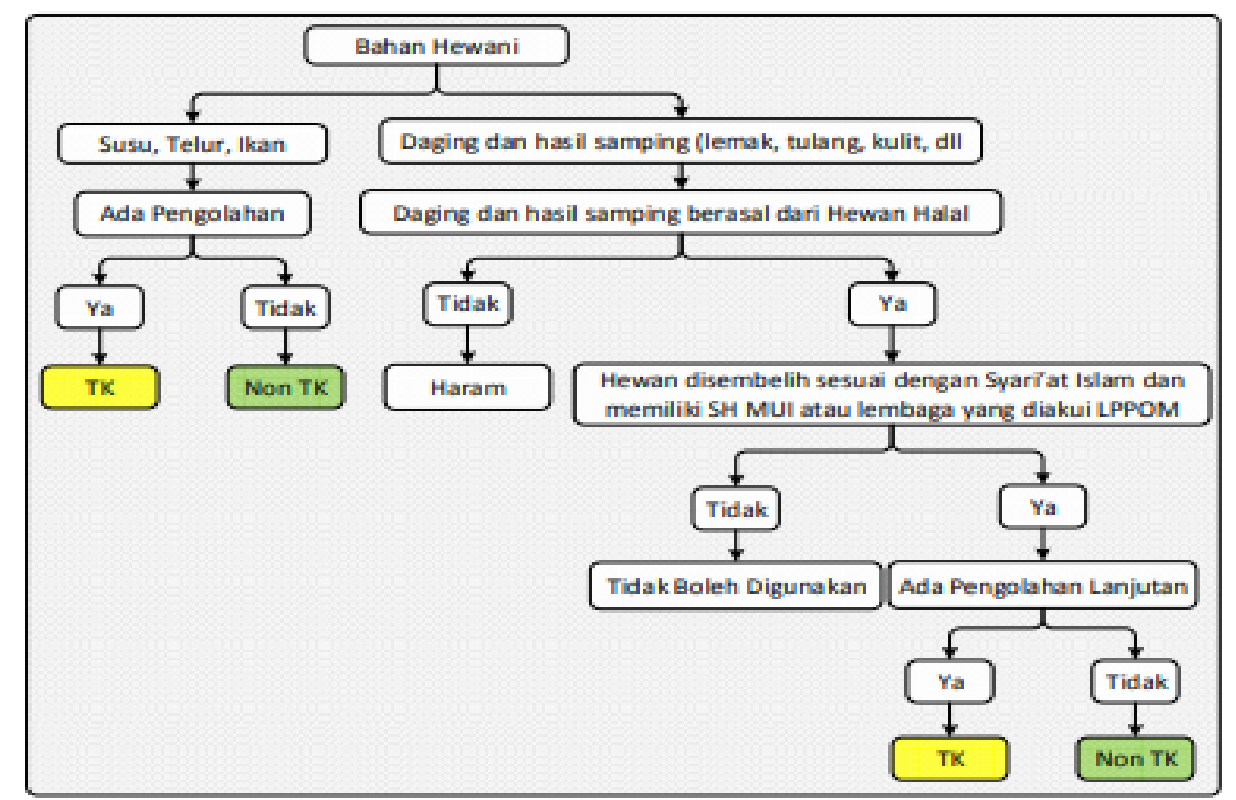

Figure 2. Identification of Halal Critical Points for Animal Materials (LPPOM MUI, 2018)

Table 3. Information on the Identification of Halal Critical Points (TK) for Animal Materials

\begin{tabular}{llcl}
\hline No & Keterangan & Penjelasan & \multicolumn{1}{c}{ Metode Pencegahan } \\
\hline $\mathbf{1}$ & TK & Critical Point & $\begin{array}{l}\text { Further study on material status determination } \\
\text { procedure }\end{array}$ \\
$\mathbf{2}$ & Non-TK & Not Critical & $\begin{array}{l}\text { Further study on material status determination } \\
\text { procedure }\end{array}$
\end{tabular}

Source : LPPOM-MUI, 2008. 
Miti Yarmunida, Nilda Susilawati, Khairiah El-Wardah

Halal Production at The Meatball Home Industry In Bengkulu City

Various testing methods were carried out to detect pork content in processed meat ingredients such as the Evagreen real-time PCR system (Amaral et al., 2017), magnetic nano particles (Seddaoui and Amine, 2020), (Kuswandi, Gani and Ahmad, 2017) to reduce fraudulent use practices. pork (Batule, Seok and Kim, 2020) in processed meat products

\section{Methods}

This type of research is a descriptive field research with a qualitative approach. Where is the procedure of the researcher as an instrument (human instrument), notebook, camera and others. Field research obtained from field research, namely looking for data by means of interviews, in order to obtain data directly by describing the data found in the field and analyzing it to get correct and accurate conclusions. The qualitative approach aims to obtain objective explanations and explanations. Furthermore, research informants are subjects who provide information about social phenomena and situations taking place in the field.

The selection of informants was taken using accidental sampling technique as many as 24 meatball traders in Bengkulu city. Primary data sources, namely data obtained directly from the subject studied in this case are meatball traders who live in the city of Bengkulu. Secondary data is additional data in the form of information that complements the primary data. Data collection techniques used preliminary observations to 1 meatball trader in Bengkulu city who has had a business for 19 years but does not have initial certification. Followed by observations to 23 meatball traders in Bengkulu city. The author also conducted interviews, namely structured interviews which were directly asked to the owner of the meatball. Documentation is used to obtain data directly from the research site. Documentation in the form of notes, books, agendas, and photos of activities to complement the data from interviews and observations or observations. The data analysis technique used in this study was the Miles and Huberman model. Namely, by reducing data, presenting data, and concluding. Data analysis by Miles and Huberman consisted of data reduction, display data, and conclusion drawing / verification which were carried out interactively and continued to completion, so that the data reached saturation consisting of data reduction, data presentation and verification. 


\section{Result and Discussion}

From the research results obtained data that the making of meatballs through several resistance until the product can be said. Sourcing of raw materials, processing of materials, storage, and marketing. As for the process of making meatballs as follows:

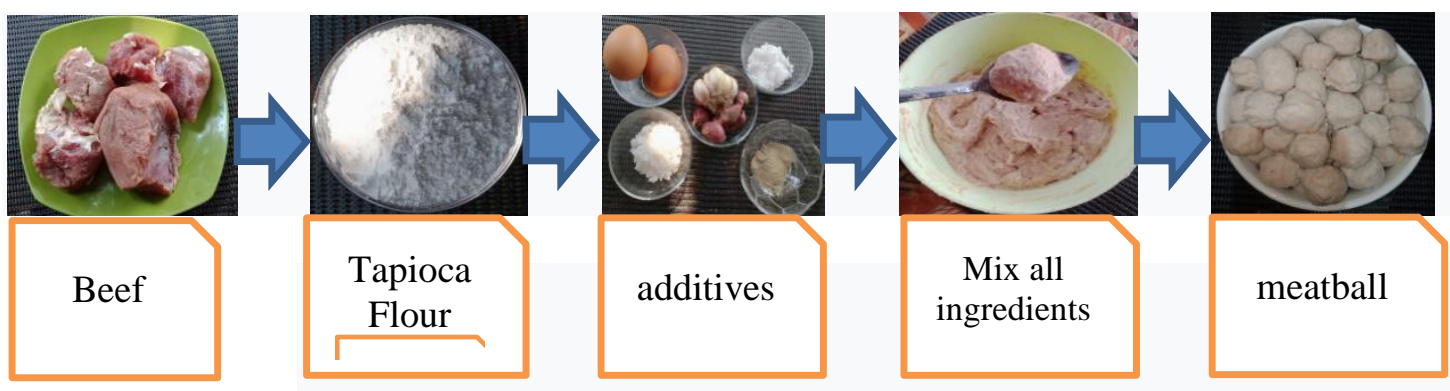

Figure 3. The Proses of making meatballs

The process of making meatballs begins with the provision of ingredients such as beef, tapioca flour, salt, pepper, eggs, shallots, garlic and flavorings. Then the meat is ground and the additional ingredients are puree. All ingredients that have been mashed are stirred until blended and formed into small circles. then boiled until it becomes meatball. According to Mena (2020) the texture of the meatballs will be tougher when boiled using boiling water and less hard when baked in the oven or sautéed. Meatballs are usually consumed with other additives such as noodles and soup or by grilling them.

The following is of the authors' findings in the field related to the meatball home industry in Bengkulu City based on the halal assurance system criteria guidelines for 24 meatball business samples obtained randomly:

Halal policy, halal producers argue that meatball products made in the home industry are halal products, because they come from halal raw materials and are properly processed according to Islamic law. Implications of halal policy have been implemented, but are not stated in the form of a written document.

Halal management team, research findings show that no meatball producer has a halal team, as described in the Halal Assurance System. However, meatball business owners apply halal provisions according to their understanding, that ingredients must be avoided from things that are prohibited and produced according to halal regulations. So that each employee understands their respective duties, but the duties and responsibilities are not designated in a written document and do not have a special team. 
Miti Yarmunida, Nilda Susilawati, Khairiah El-Wardah

Halal Production at The Meatball Home Industry In Bengkulu City

Training and education. The owner of a meatball business never conducts training for employees, be it once or twice a year. Halal understanding is only obtained from print and electronic media as well as social media. The education of the halal guarantee system has not been clearly understood because there has been no socialization from LPPOM MUI about the obligation for meatball business owners to conduct training and education for employees. So far, it is understood that every meatball producer must have a halal certificate, but the procedure is not clearly understood

The raw materials used in the manufacture of meatballs come from fresh beef purchased from meat traders mixed with raw materials such as sago flour, salt, and flavorings. From the research results, all producers use almost the same ingredients, some are mixed with beef and chicken for making meatballs. Additional ingredients such as sago flour, salt, flavorings are used, according to the manufacturer's recognition that they already have the MUI halal logo on the product packaging, so producers believe that processed beef products are halal.

The resulting meatball products are home industry products with tastes and odors that do not lead to things that are haram and harmful to humans. This is evidenced by the manufacturer's acknowledgment that the sample test results of the Bengkulu City Industry and Trade Service show that the meatballs produced do not contain harmful ingredients and are fit for consumption. Meatball checks are also carried out regularly every year to ensure that the ingredients contained in meatballs do not change and are dangerous.

Production facilities, from the results of research, that all meatball producers have used facilities in accordance with Islamic law, but the use of beef from traders in the market does not come from halal-certified slaughterhouses $(\mathrm{RPH})$. A beef mill in the market is a mill that does not specifically grind beef, but also other meats, such as chicken, fish, and other meats. This makes it possible for the equipment to grind beef to also be used to grind other meats, such as pork and other animals which are prohibited without the knowledge of the manufacturer. This allows beef to come to a critical point of product shelf life if not properly monitored.

A critical activity is written procedures. The findings showed that the meatball producers did not record the critical activity procedures of the manufacturing process and the materials used in the meatball making. However, it is believed that all processes and materials used are in accordance with halal procedures and using halal materials. It's just that there is no written procedure for critical activities. 
Traceability, from the findings shows that traceability can be well explained by meatball producers, starting from the ingredients used that are labeled halal and only meat and meat mills that have not been certified halal. This is because in the city of Bengkulu there is only one slaughterhouse that is certified by the LPPOM MUI Bengkulu. In addition, the location of the market which is close to the house and has become a customer of meat traders makes producers reluctant to move to certified slaughterhouses. It's just that the search process is not well documented in the form of a written document, it can only be explained in oral form by the meatball producer. Whereas in the halal assurance system, traceability can be proven by written documents, to make it easier for auditors to check existing data.

Handling of products that do not meet the criteria. For products that do not meet the criteria, meatball producers discard the product to avoid damage to other products. However, based on the findings, it is rare for a product that does not meet the criteria, because the meatball-making process is carried out every day, making the meatball production rarely fail because it has become a habit. In addition, the materials used are the ingredients of choice commonly used in the manufacture of meatballs, by taking into account the quality of the meatball additives and the volume of their output. This is very concerned about so that the quality of the meatball production is guaranteed, to maintain customer trust.

Internal audit. In writing, an audit has never been carried out, because the meatball producer is a small business that has not implemented management like a company. However, to ensure quality, the ingredients of the meatball production are always evaluated on the ingredients and the production process, in order to obtain good meatballs, both in taste and elasticity. If the ingredients used, such as flour, do not show good quality, they will be replaced with other ingredients. Likewise with the quality of the meat and other additives. And according to their explanation that the materials and production processes have been carried out according to the halal criteria, even though there has never been an internal audit. Management review. The findings show that meatball producers undergo a management review. If in the management stages that are applied there are obstacles and evaluation so that the existing management is continuously improved to facilitate the evaluation process. The management system for the meatball business is not in a complete written form with Production Operational Standards, only applied in oral form, because there are not too many employees and some management is also written in writing to make it easier for employees to remember and understand the rules set by the parties. management. 
Miti Yarmunida, Nilda Susilawati, Khairiah El-Wardah

Halal Production at The Meatball Home Industry In Bengkulu City

The description of the research findings shows that the halal guarantee system as a whole has not been implemented properly by meatball businessmen in Bengkulu City. The majority of halal assurance systems and management are not written in the form of a written document, making it difficult to carry out searches and audits. Business actors or producers understand that the halal guarantee system is only that the ingredients and the production process do not contain pork or unclean which is prohibited in religion.

Halal management is also a serious concern for LPPOM MUI or BPJPH, because the results of the research are that there are no meatball business actors who carry out halal management as referred to in the Halal Assurance System. Education and training are needed for business actors to understand and apply the halal assurance system in meatball production. So far, only BPOM has received assistance regarding the content of meatballs, whether they contain harmful substances or pork. But not yet at the halal management education stage.

The government is expected to collaborate with various agencies such as universities, the Ministry of Religion, BPOM and other institutions to periodically provide socialization and education to the public regarding the halal guarantee system as regulated in Law No. 33 of 2014. In the future all food products will get halal certification, thus providing halal assurance and a sense of calm for the Muslim community in consuming meatball.

\section{Conclusion}

From the research results, it can be concluded that the meatball production carried out is only one producer that has implemented the halal guarantee system, while the rest are still in process or have only implemented some of the 11 criteria for the halal assurance system, socialization and strengthening of literacy is still needed to provide more in-depth information about halal certification. This is due to the ignorance of producers in implementing the halal assurance system and certification of halal products. More in-depth research is needed, especially regarding the supply chain for processed beef products in order to provide a sense of security and calm for consumers in consuming meatballs and animalbased products.

\section{References}

Ahmad, A. N., Rahman, A. A. and Rahman, S. A. (2015) 'Assessing Knowledge and Religiosity on Consumer Behavior towards Halal Food and Cosmetic Products', International Journal of Social Science and Humanity, 5(1), pp. 10-14. doi: 10.7763/ijssh.2015.v5.413.

Amaral, J. S. et al. (2017) 'Quantitative detection of pork meat by EvaGreen real-time PCR 
to assess the authenticity of processed meat products', Food Control. Elsevier Ltd, 72, pp. 53-61. doi: 10.1016/j.foodcont.2016.07.029.

Baharuddin, Kasmarini dan Ahmad Kassim, Norliya dan Nordin, Siti Khairiyah dan Buyong, S. Z. (2015) 'Understanding the halal concept and the importance of information on halal food business needed by potential Malaysian entrepreneurs', International Journal of Academic Research in Business and Social Sciences, pp. 170-180. Available at: http://uitmprepo.uitm.edu.my/34/.

Batule, B. S., Seok, Y. and Kim, M. G. (2020) 'An innovative paper-based device for DNA extraction from processed meat products', Food Chemistry. Elsevier, 321(November 2018), p. 126708. doi: 10.1016/j.foodchem.2020.126708.

Carthy, Jerome, P. \& W. (2003) Dasar-dasar Pemasaran. Jakarta: Erlangga.

Faridah, H. (2019) 'Halal Certification in Indonesia: History, Development and Implementation of Halal', Halal Product and Research, 2, p. 1.

Fauzia, I. Y. and Royadi, A. K. (2014) PRINSIF DASAR EKONOMI ISLAM, Perspektif Maqasid Syariah.

Gemasih, D. (2014) PEMETAAN TITIK KRITIS HALAL PADA ALUR PROSES RANTAI PASOK PRODUK AGROINDUSTRI BERBASIS DAGING SAPI DI $J A W A B A R A T$ (STUDI KASUS: BAKSO SAPI KEMASAN). Universitas Padjajaran. Available

at: https://repository.unpad.ac.id/frontdoor/index/index/year/2020/docId/36670.

Hapsari, D. R. et al. (2019) 'Studi Kasus Pengaruh Logo Halal dan Kesadaran Halal terhadap Keputusan Pembelian Bakso Sapi di Ciawi - Bogor', Jurnal Agroindustri Halal, 5(2), pp. 196-203. doi: 10.30997/jah.v5i2.1965.

Karim, A. (2007) Ekonomi Mikro Islam. Raja Grafindo Persada.

Kuswandi, B., Gani, A. A. and Ahmad, M. (2017) 'Immuno strip test for detection of pork adulteration in cooked meatballs', Food Bioscience. Elsevier Ltd, 19, pp. 1-6. doi: 10.1016/j.fbio.2017.05.001.

Marzuki, S. Z. S., Hall, C. M. and Ballantine, P. W. (2014) 'Measurement of Restaurant Manager Expectations toward Halal Certification Using Factor and Cluster Analysis', Procedia - Social and Behavioral Sciences. Elsevier B.V., 121, pp. 291-303. doi: 10.1016/j.sbspro.2014.01.1130.

Mena, B. (2020) 'Influence of cooking method, fat content and food additives on physicochemical and nutritional properties of beef meatballs fortified with sugarcane fibre', International Journal of Food Science and Technology, 55(6), pp. 2381-2390. doi: 10.1111/ijfs.14482.

Mohtar, N. M., Amirnordin, N. A. and Haron, H. (2014) 'Ayamas Food Corporation Sdn. Bhd: A Study on the Factors of Consumer Behaviour towards Halal Product Selection', Procedia - Social and Behavioral Sciences. Elsevier B.V., 121(September 2012), pp. 166-185. doi: 10.1016/j.sbspro.2014.01.1118.

Purnomo, D., Pujianto, T. and Maulana, R. (2015) 'Information System Development on Halal Supply Chain Traceability (Case Study: Supply Chain of Beef Meat Balls)', Journal Of Halal Research, 1(1), pp. 3-5.

Sardiana, A. (2020) 'Halal Literacy and Halal Product Purchase Dimension: A Preliminary Study', Insight Journal, (March). doi: 10.13140/RG.2.2.31540.81284.

Seddaoui, N. and Amine, A. (2020) 'A sensitive colorimetric immunoassay based on poly(dopamine) modified magnetic nanoparticles for meat authentication', Lwt. Elsevier, 122(November 2019), p. 109045. doi: 10.1016/j.lwt.2020.109045.

Segati, A. (2018) 'Pengaruh Persepsi Sertifikasi Halal, Kualitas Produk, Dan Harga Terhadap Persepsi Peningkatan Penjualan', JEBI (Jurnal Ekonomi dan Bisnis Islam), 3(2), p. 159. 
Miti Yarmunida, Nilda Susilawati, Khairiah El-Wardah

Halal Production at The Meatball Home Industry In Bengkulu City

doi: $10.15548 /$ jebi.v3i2.175.

SNI 3818 (2014) Syarat Mutu Bakso Daging.

Zainuddin, N. et al. (2019) 'Effect of Halal certification and labelling process on Halal supply chain performance', International Journal of Supply Chain Management, 8(4), pp. 1075-1081.

Ahmad, A. N., Rahman, A. A. and Rahman, S. A. (2015) 'Assessing Knowledge and Religiosity on Consumer Behavior towards Halal Food and Cosmetic Products', International Journal of Social Science and Humanity, 5(1), pp. 10-14. doi: 10.7763/ijssh.2015.v5.413.

Amaral, J. S. et al. (2017) 'Quantitative detection of pork meat by EvaGreen real-time PCR to assess the authenticity of processed meat products', Food Control. Elsevier Ltd, 72, pp. 53-61. doi: 10.1016/j.foodcont.2016.07.029.

Baharuddin, Kasmarini dan Ahmad Kassim, Norliya dan Nordin, Siti Khairiyah dan Buyong, S. Z. (2015) 'Understanding the halal concept and the importance of information on halal food business needed by potential Malaysian entrepreneurs', International Journal of Academic Research in Business and Social Sciences, pp. 170-180. Available at: http://uitmprepo.uitm.edu.my/34/.

Batule, B. S., Seok, Y. and Kim, M. G. (2020) 'An innovative paper-based device for DNA extraction from processed meat products', Food Chemistry. Elsevier, 321(November 2018), p. 126708. doi: 10.1016/j.foodchem.2020.126708.

Carthy, Jerome, P. \& W. (2003) Dasar-dasar Pemasaran. Jakarta: Erlangga.

Faridah, H. (2019) 'Halal Certification in Indonesia: History, Development and Implementation of Halal', Halal Product and Research, 2, p. 1.

Fauzia, I. Y. and Royadi, A. K. (2014) PRINSIF DASAR EKONOMI ISLAM, Perspektif Maqasid Syariah.

Gemasih, D. (2014) PEMETAAN TITIK KRITIS HALAL PADA ALUR PROSES RANTAI PASOK PRODUK AGROINDUSTRI BERBASIS DAGING SAPI DI JAW A BARAT (STUDI KASUS: BAKSO SAPI KEMASAN). Universitas Padjajaran. Available

at: https://repository.unpad.ac.id/frontdoor/index/index/year/2020/docId/36670.

Hapsari, D. R. et al. (2019) 'Studi Kasus Pengaruh Logo Halal dan Kesadaran Halal terhadap Keputusan Pembelian Bakso Sapi di Ciawi - Bogor', Jurnal Agroindustri Halal, 5(2), pp. 196-203. doi: 10.30997/jah.v5i2.1965.

Karim, A. (2007) Ekonomi Mikro Islam. Raja Grafindo Persada.

Kuswandi, B., Gani, A. A. and Ahmad, M. (2017) 'Immuno strip test for detection of pork adulteration in cooked meatballs', Food Bioscience. Elsevier Ltd, 19, pp. 1-6. doi: 10.1016/j.fbio.2017.05.001.

Marzuki, S. Z. S., Hall, C. M. and Ballantine, P. W. (2014) 'Measurement of Restaurant Manager Expectations toward Halal Certification Using Factor and Cluster Analysis', Procedia - Social and Behavioral Sciences. Elsevier B.V., 121, pp. 291-303. doi: 10.1016/j.sbspro.2014.01.1130.

Mena, B. (2020) 'Influence of cooking method, fat content and food additives on physicochemical and nutritional properties of beef meatballs fortified with sugarcane fibre', International Journal of Food Science and Technology, 55(6), pp. 2381-2390. doi: $10.1111 /$ ijfs.14482.

Mohtar, N. M., Amirnordin, N. A. and Haron, H. (2014) 'Ayamas Food Corporation Sdn. Bhd: A Study on the Factors of Consumer Behaviour towards Halal Product Selection', Procedia - Social and Behavioral Sciences. Elsevier B.V., 121(September 2012), pp. 166-185. doi: 10.1016/j.sbspro.2014.01.1118.

Purnomo, D., Pujianto, T. and Maulana, R. (2015) 'Information System Development on 
Halal Supply Chain Traceability (Case Study: Supply Chain of Beef Meat Balls)', Journal Of Halal Research, 1(1), pp. 3-5.

Sardiana, A. (2020) 'Halal Literacy and Halal Product Purchase Dimension: A Preliminary Study', Insight Journal, (March). doi: 10.13140/RG.2.2.31540.81284.

Seddaoui, N. and Amine, A. (2020) 'A sensitive colorimetric immunoassay based on poly(dopamine) modified magnetic nanoparticles for meat authentication', Lwt. Elsevier, 122(November 2019), p. 109045. doi: 10.1016/j.lwt.2020.109045.

Segati, A. (2018) 'Pengaruh Persepsi Sertifikasi Halal, Kualitas Produk, Dan Harga Terhadap Persepsi Peningkatan Penjualan', JEBI (Jurnal Ekonomi dan Bisnis Islam), 3(2), p. 159. doi: $10.15548 /$ jebi.v3i2.175.

SNI 3818 (2014) Syarat Mutu Bakso Daging.

Zainuddin, N. et al. (2019) 'Effect of Halal certification and labelling process on Halal supply chain performance', International Journal of Supply Chain Management, 8(4), pp. 1075-1081. 